\title{
PENGARUH UMUR DAUN PALA DAN JENIS PENGERINGAN TERHADAP SIFAT KIMIA DAN ORGANOLEPTIK TEH HERBAL DAUN PALA
}

\author{
Maya Lestari ${ }^{*}{ }^{*}$, Erna Rusliana Muhammad Saleh ${ }^{2}$, Hamidin Rasulu $^{3}$ \\ 1,2,3 Program studi Teknologi Hasil Pertanin Universitas Khairun \\ * Corresponding Authors: mlestari267@gmail.com \\ Manuscript received: 16-09-2018, Revision accepted: 05-11-2018
}

\begin{abstract}
Abstrak
Tujuan penelitian ini adalah mengetahui pengaruh umur daun pala dan jenis pengeringan yang digunakan terhadap sifat kimia dan organoleptik teh herbal daun pala yang dihasilkan. Penelitian ini menggunakan metode Rancangan Acak Kelompok (RAK) faktorial. Variabel pokok dalam penelitian ini adalah analisis sifat kimia (antioksidan, kadar air, kadar abu, dan serat kasar) dan organoleptik (rasa, warna dan aroma). Teh herbal daun pala tua dan muda dengan dua jenis pengeringan memiliki sifat kimia yaitu : antioksidan 59,71\%-76,83\%, kadar air 6,64-7,52\%, kadar abu 4,77\%-6,66\% dan serat kasar $17,66 \%-24,02 \%$. sifat organoleptik yaitu : rasa 3,06\%-3,41\%, aroma 3,08\%-3,48\% dan warna 3,06\%-3,25\%. Teh herbal daun pala perlakuan terbaik yaitu daun pala muda dengan pengeringan matahari (MM).
\end{abstract}

Kata Kunci : Teh herbal daun pala, daun pala, umur daun pala, jenis pengeringan, sifat kimia, sifat organoleptik.

\begin{abstract}
The purpose of this study for knowing the influnces by ege of nutmeg's leaf and the type of drying are used to chemical and organoleptic properties of herbal tea by nutmeg's leaf that produced. This study uses a randomized's cluster design (RAK) factorial. Principal variable in this research is the analysis of chemical properties (antioxidant, moisture content, ash content, and crude fiber) and organoleptic (taste, color and smell).the old nutmeg's leaf and the young with two drying type have chemical properties, namely: antioxidants $59.71 \%-76.83 \%$, from 6.64 to $7.52 \%$ moisture content, ash content of $4.77 \%-6.66 \%$ and crude fiber $17.66 \%-24.02 \%$. organoleptic properties: a sense of 3,06\% $-3,41 \%, 3,08 \%-$ $3,48 \%$ aroma and color of $3,06 \%-3,25 \%$. Herbal tea leaf is the best treatment young old nutmeg with a sun drying $(\mathrm{MM})$.
\end{abstract}

Keywords: Herbal tea of nutmeg's leaf, nutmeg's leaf, the age of nutmeg's, the drying type, chemical organoleptic properties. 


\section{PENDAHULUAN}

Tanaman pala (Myristica fragrans Houtt) adalah tanaman asli Indonesia. Tanaman pala termasuk dalam famili Myristicaceae merupakan tanaman khas Indonesia. Tanaman ini banyak dihasilkan di kepulauan Maluku dan pulau-pulau sekitarnya. Potensi komoditi pala di Maluku Utara tercatat 24.122 ha yang merupakan perkebunan rakyat dengan total produksi sebesar 2.756 ton/tahun. Produktivitas tertinggi di kabupaten Halmahera Utara sebesar 1.313 ton (BPS Maluku Utara, 2014). Selain sebagai rempah-rempah, pala juga berfungsi sebagai tanaman penghasil minyak atsiri yang banyak digunakan dalam industri pengalengan, minuman dan kosmetik.

Minyak atsiri yang dihasilkan dari pala, umumnya berasal dari biji dan fuli pala. Namun, daun pala juga memili minyak atsiri. Minyak atsiri daun pala diketahui memiliki 33 komponen kimia dan 5 komponen kimia terbesarnya adalah sabinene, terpinene-4-ol, apinene, $\beta$-pinene, and $\beta$-phellandrene. Minyak atsiri daun pala terbukti memiliki aktivitas antibakteri terhadap $S$. aureus dengan KHTM pada konsentrasi minyak atsiri 3,125\% menghasilkan zona hambat sebesar $16,81 \mathrm{~mm}$ dan terhadap E. coli dengan KHTM pada konsentrasi minyak atsiri 1\% menghasilkan zona hambat sebesar 0,54 $\mathrm{mm}$ (Rastuti, Widyaningsih dan Ningsih, 2013).

Selama ini hanya daging, biji dan fulinya saja yang dimanfaatkan menjadi beragam produk, padahal daun pala mengandung potensi kimia yang bermanfaat untuk kesehatan. Oleh karena itu peneliti akan memanfaatkan daun pala untuk dibuat menjadi teh herbal, baik daun pala muda maupun tua.

Dalam pembuatan teh proses pengeringan sangat berpengaruh penting terhadap mutu dan kandungan kimia pada teh. Jenis pengeringan yang biasa digunakan untuk pembuatan teh dalam skala kecil yaitu pengeringan menggunakan oven dan matahari. Bagaimana pengaruh dari kedua umur daun pala dan kedua jenis pengeringan tersebut terhadap sifat kimia dan organoleptik teh herbal daun pala, menjadi sesuatu yang belum diketahui. Oleh karena itu penelitian ini mengkaji hal tersebut. Diharapkan nantinya penelitian ini dapat mengetahui umur daun pala dan jenis pengeringan yang berpotensi memiliki sifat kimia dan organoleptik yang terbaik. Tujuan penelitian ini adalah mengetahui pengaruh umur daun pala dan jenis pengeringan yang digunakan terhadap sifat kimia dan organoleptik teh herbal daun pala yang dihasilkan. Manfaat dari penelitian ini adalah; (1) Dapat memberikan informasi tentang jenis pengeringan dan umur daun pala yang paling tepat untuk pembuatan teh herbal daun pala, (2) Membuka peluang usaha bagi industri lokal di Maluku Utara khususnya di Ternate dalam bentuk teh herbal dari daun pala sebagai oleh-oleh khas Ternate, dan (3) Meningkatkan potensi lokal Maluku Utara.

\section{METODE PENELITIAN}

Pembuatan teh daun pala dan analisa sifat organoleptik serta analisis kimia pada kadar air dan kadar abu, dilakukandi Laboratorium Teknologi Hasil Pertanian (THP) Fakultas Pertanian Universitas Khairun Ternate. Analisis sifat kimia yaitu antioksidan dan serat kasar 
Lestari, M., dkk. Teh herbal daun pala, daun pala, umur daun pala, jenis pengeringan, sifat kimia, sifat organoleptik

dilakukan di Laboratorium Teknologi Pangan Fakultas Teknologi Pangan UGM Yogyakarta.

Bahan yang digunakan dalam pembuatan teh adalah daun pala muda, daun pala tua dan kantung teh. Bahan untuk pengujian antioksidan meliputi: 4,0 Ml larutan DPPH 0,07 mM, methanol $100 \mathrm{ml}$. Bahan untuk pengujian serat kasar meliputi: soxlet, pelarut organic, $\mathrm{H}_{2} \mathrm{SO}_{4}$, $\mathrm{NaOH}$, air panas dan etanol.

Peralatan yang digunakan dalam penelitian ini meliputi alat untuk pembuatan produk: loyang / nampan, oven, blender, pisau, serbet, tisu, sendok kecil, kertas label, timbangan analitik. Alat yang digunakan untuk pengujian antioksidan meliputi: spektrofotometer UVVIS, labu ukur. Alat pengujian kadar air meliputi: oven, cawan kosong, timbangan untuk mengukur kadar air. Alat yang digunakan untuk pengujian kadar abu meliputi: cawan, tanur, muffle furnace dan deksikator. Alat yang digunakan untuk pengujian serat kasar meliputi: erlenmeyer, corong Buchner, kertas saring. Alat yang digunakan untuk uji organoleptik meliputi: gelas sloki, nampan, kertas label, aqua, sendok mini, tisu dan kuisioner.

\section{Rancangan Penelitian}

Penelitian ini menggunakan metode Rancangan Acak Kelompik (RAK) faktorial. Terdapat dua faktor yang diuji, yaitu umur daun pala dan jenis pengeringan. Faktor pertama adalah umur daun pala $(\mathrm{D})$ yang terdiri dari :

1 : Daun pala tua

2 : Daun pala muda

Faktor yang kedua adalah jenis pengeringan $(\mathrm{P})$ yang terdiri dari :

1 : Oven (suhu $50^{\circ} \mathrm{C}$ ) selama 150 menit

2 : Matahari selama 2 hari $(2 \times 24 \mathrm{Jam})$

Setiap taraf perlakuan dikombinasikan dan setiap unit perlakuan diulang sebanyak 3 kali sehingga akan memperoleh 12 unit percobaan. Denah percobaan faktorial dengan menggunakan rancangan dasar Rancangan Acak Lengkap (RAK).

\section{Variabel Penelitian}

Variabel pokok dalam penelitian ini adalah analisis sifat kimia (antioksidan, kadar air, kadar abu, dan serat kasar) dan organoleptik (rasa, warna dan aroma).

\section{Prosedur Analisa:}

a. Persiapan bahan

Daun pala tua dan muda diambil lalu disortir. Tujuannya adalah untuk memisahkan antara daun pala yang sudah tua dan yang muda.

\section{b. Pelayuan}

Pelayuan daun pala tua dan muda dengan cara diangin-anginkan di suhu ruang selama 24 jam. Tujuan dari proses pelayuan ini adalah mengurangi kadar air hingga tingkat layu 
tertentu dan juga sebagai proses fermentasi, daun pala diletakkan diatas nampan sehingga enzim-enzim yang ada di dalam daun bersentuhan dengan udara dan mulai teroksidasi. Hal inilah yang menghasilkan bau, warna, dan mutu dari teh.

c. Pengecilan ukuran

Proses selanjutnya adalah pengecilan ukuran dengan cara daun dipotong-potong menggunakan pisau hingga menjadi ukuran yang lebih kecil. Tujuannya adalah untuk memperluas permukaan daun agar proses daun pala lebih cepat kering.

\section{d. Proses pengeringan}

Proses pengeringan yang dilakukan sesuai dengan perlakuan yang diuji. Ada 2 proses pengeringan yang digunakan, yang pertama menggunakan pengeringan alami yaitu matahari, daun dijemur hingga 2 hari. Kemudian yang kedua menggunakan oven dengan suhu $50{ }^{\circ} \mathrm{C}$ selama 150 menit.

\section{e. Penghalusan daun}

Daun teh yang sudah kering kemudian dihaluskan kembali menggunakan blender. Tujuannya untuk memudahkan pelepasan komponen teh saat penyeduhan.

\section{f. Pengemasan}

Teh yang sudah diblender, kemudian ditimbang menggunakan timbangan seberat 2 gram lalu dikemas menggunakan kantong teh yang sudah disiapkan.

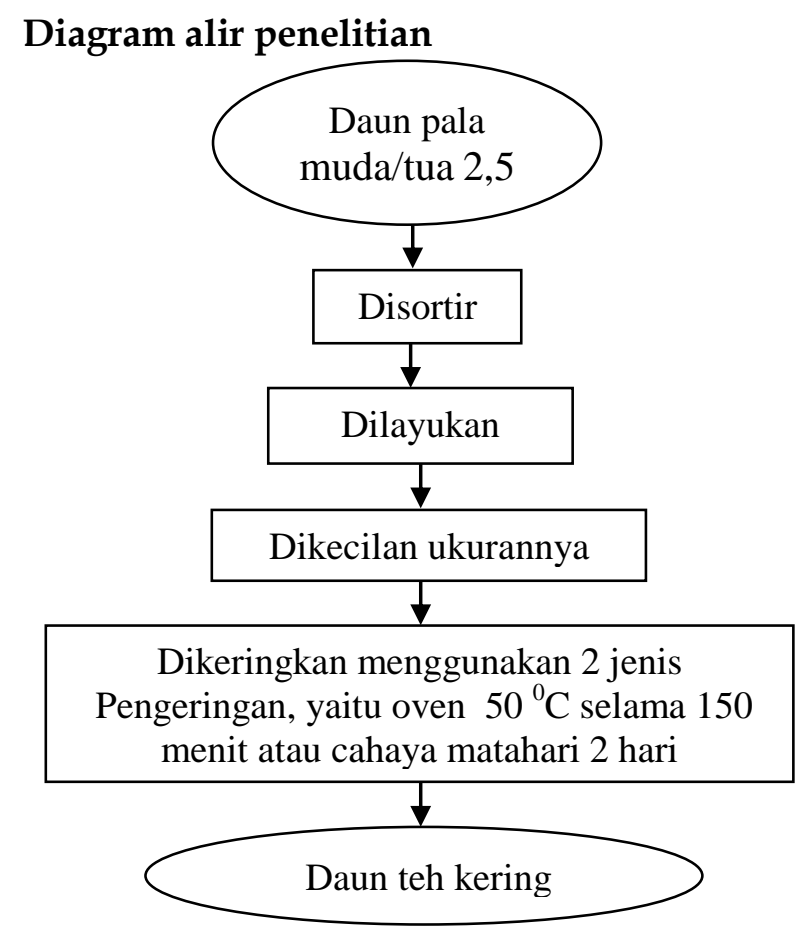


Lestari, M., dkk. Teh herbal daun pala, daun pala, umur daun pala, jenis pengeringan, sifat kimia, sifat organoleptik

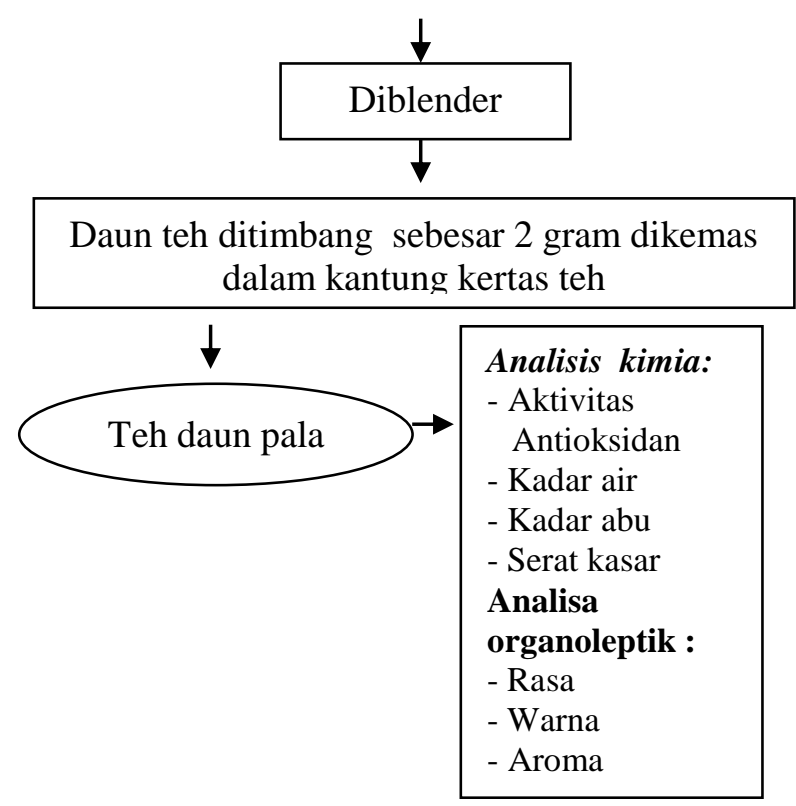

Gambar 3. Diagram alir pembuatan teh daun pala (Sari, 2013).

\section{Analisis Penelitian}

Adapun analisa sifat kimia yang dilakukan pada penelitian ini adalah antioksidan, kadar air, kadar abu, serat kasar dan organoleptik.

\section{HASIL DAN PEMBAHASAN}

\section{A. Aktivitas Antioksidan}

Antioksidan adalah senyawa yang mampu menghambat laju oksidasi molekul lain atau menetralisir radikal bebas (Fajriah dkk, 2007). Senyawa flavonoid adalah untuk menangkal radikal bebas. Radikal bebas dapat berkembang dengan melakukan oksidasi terhadap sel-sel sehat.

Rata-rata nilai aktivitas antioksidan teh herbal daun pala tua dan muda dengan dua jenis pengeringan dapat dilihat pada Gambar 4.

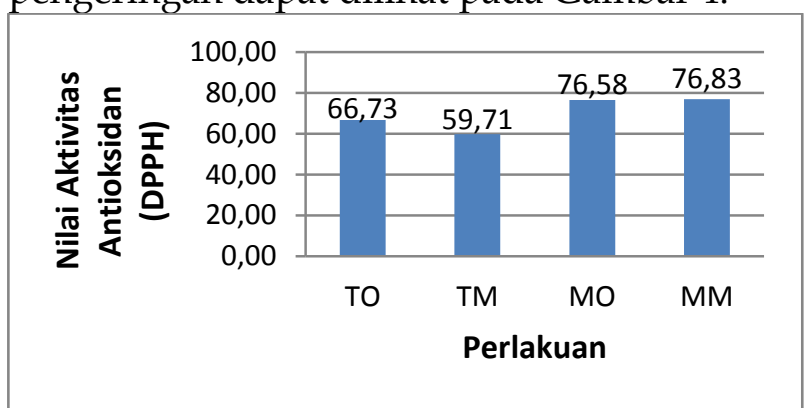

Gambar 4. Grafik rata-rata nilai aktivitas antioksidan teh herbal daun pala tua dan muda dengan dua jenis pengeringan 
Berdasarkan Gambar 4, terlihat bahwa nilai rata-rata aktivitas antioksidan pada teh herbal daun pala tua dan muda, dengan dua jenis pengeringan yaitu oven dan matahari berbeda jauh, nilai aktivitas antioksidannya berkisar antara 59,71\%-76,83\%. Nilai aktivitas antioksidan teh herbal daun pala yang tertinggi yaitu $76,83 \%$ pada perlakuan MO dan yang terendah pada perlakuan TM 59,71\%. Pada gambar diatas terlihat pada perlakuan TO-MM menunjukkan bahwa semakin muda umur daun pala maka semakin tinggi aktivitas antioksidannya, serta semakin cepat proses pengeringan maka akan semakin tinggi pula aktivitas antioksidannya. Hartanti dan Sri (2009) menunjukkan ba hwa perbedaan perlakuan preparasi bahan baku berpengaruh pada sifat antioksidan. Pada bahan baku yang mengalami proses pengeringan beberapa senyawa aktivitas antioksidan mengalami kerusakan sehingga aktivitas antioksidannya turun.

Hasil analisis sidik ragam terhadap teh herbal daun pala menunjukkan bahwa umur daun pala berbeda nyata terhadap aktivitas antioksidan teh herbal daun pala yang dihasilkan pada taraf 5\%. Hasil Beda Nyata Terkecil (BNT) berdasarkan nilai aktivitas antioksidan pada perlakuan umur daun, dapat disimpulkan bahwa teh herbal daun pala pada perlakuan umur daun berbeda antara umur daun tua $(\mathrm{T})$ dan umur daun muda $(\mathrm{M})$. Hal ini menunjukkan bahwa semakin muda umur daun maka semakin tinggi aktivitas antioksidan yang dihasilkan.

Tabel 6. Aktivitas Antioksidan Akibat Pengaruh Umur Daun Pada Uji BNT $t_{(0,05)}=20,53$

\begin{tabular}{ccc}
\hline Umur & Rata-rata & Notasi \\
\hline Tua & 66,73 & $\mathrm{ab}$ \\
Muda & 76,58 & $\mathrm{a}$
\end{tabular}

Keterangan : subscript yang diikuti huruf yang sama dinyatakan tidak berbeda nyata pada uji BNT $t_{(0,05)}$

\section{B. Kadar Air}

Kadar air merupakan komponen penting dalam bahan pangan yang dapat mempengaruhi penampakan tekstur serta cita rasa makanan. Kandungan kadar air dalam bahan pangan menentukan daya terima, kesegaran, dan daya tahan bahan. Kadar air merupakan jumlah air total yang terkandung dalam bahan pangan tanpa memperhatikan kondisi atau derajat keterikatan air (Syarief dan Halid, 1993).

Analisa rata-rata nilai kadar air teh herbal daun pala tua dan muda dengan dua jenis pengeringan dapat dilihat pada Gambar 5.

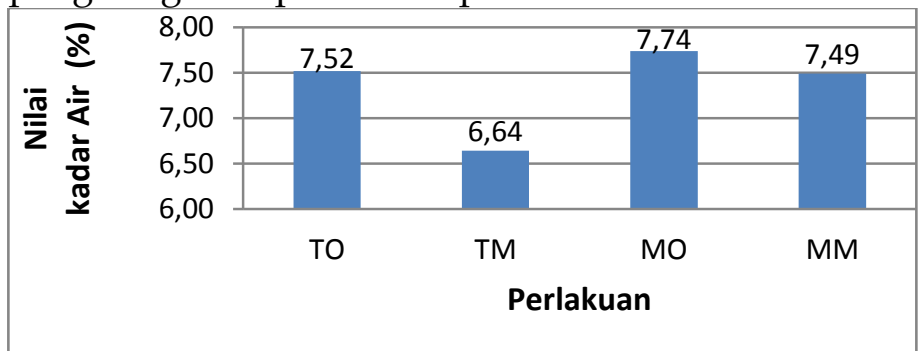

Gambar 5. Grafik rata-rata nilai kadar air teh herbal daun pala tua dan muda dengan dua jenis pengeringan. 
Lestari, M., dkk. Teh herbal daun pala, daun pala, umur daun pala, jenis pengeringan, sifat kimia, sifat organoleptik

Berdasarkan Gambar 5, terlihat bahwa kadar air pada teh herbal daun pala tua dan muda dengan dua jenis pengeringan yaitu oven dan matahari berkisar antara 6,64\%-7,52\%. Nilai kadar air teh herbal daun pala yang terendah yaitu $6,64 \%$ pada perlakuan TM, dan yang tertinggi yaitu 7,74\% pada perlakuan MO. Perlakuan MO mempunyai kadar air yang lebih tinggi dibandingkan dengan perlakuan TO, TM dan MM. Hal ini menunjukkan bahwa jenis pengeringan dan umur daun sangat berpengaruh penting terhadap tinggi rendahnya kadar air dalam suatu bahan pangan. Termasuk pada produk teh herbal daun pala ini. Penurunan nilai kadar air ini berlangsung dengan semakin lamanya proses pengeringan. Martiningrum (2005) menyatakan bahwa waktu pengeringan yang akan menyebabkan molekul-molekul air yang bergerak meninggalkan bahan dalam bentuk uap air juga berbeda-beda.

Kadar air teh herbal daun pala ini memiliki nilai kadar air lebih rendah dibanding dengan nilai kadar air pada ketetapan SNI yaitu maksimal 8\%, ini artinya kadar air dari teh herbal yang dibuat sudah memenuhi standar SNI.

Hasil analisis sidik ragam menunjukkan bahwa umur daun dan jenis pengeringan berbeda nyata terhadap nilai kadar air yang dihasilkan. Tidak ada interaksi antara umur daun dan jenis pengeringan. Hasil Beda Nyata Terkecil (BNT) Berdasarkan nilai kadar air pada perlakuan umur daun dan jenis pengeringan dapat disimpulkan bahwa teh herbal daun pala pada perlakuan umur daun berbeda antara umur daun tua (T) dan umur daun muda (M), sedangkan pada perlakuan jenis pengeringan juga berbeda antara pengeringan oven $(\mathrm{O})$ dan matahari (M).

Tabel 7. Kadar air akibat pengaruh umur daun dan jenis pengeringan pada uji BNT $t_{(0,05)}=$ 0,078

\begin{tabular}{ccc}
\hline Perlakuan & Rata-rata & Notasi \\
\hline Umur & & \\
\hline Tua & 7,52 & $\mathrm{a}$ \\
Muda & 7,74 & $\mathrm{ab}$ \\
\hline Pengeringan & & \\
\hline Oven & 6,64 & $\mathrm{a}$ \\
Matahari & 7,49 & $\mathrm{~b}$
\end{tabular}

Keterangan : subscript yang diikuti huruf yang sama dinyatakan tidak berbeda nyata pada uji BNT $t_{(0,05)}$

\section{Kadar Abu}

Kadar abu merupakan parameter untuk menunjukkan nilai kandungan bahan anorganik (mineral) yang ada di dalam suatu bahan atau produk. Semakin tinggi nilai kadar abu maka semakin banyak kandungan bahan anorganik di dalam produk tersebut. Komponen bahan anorganik di dalam suatu bahan sangat bervariasi baik jenis maupun jumlahnya (Roni, 2008).

Analisa rata-rata nilai kadar abu teh herbal daun pala tua dan muda dengan dua jenis pengeringan dapat dilihat pada Gambar 6. 


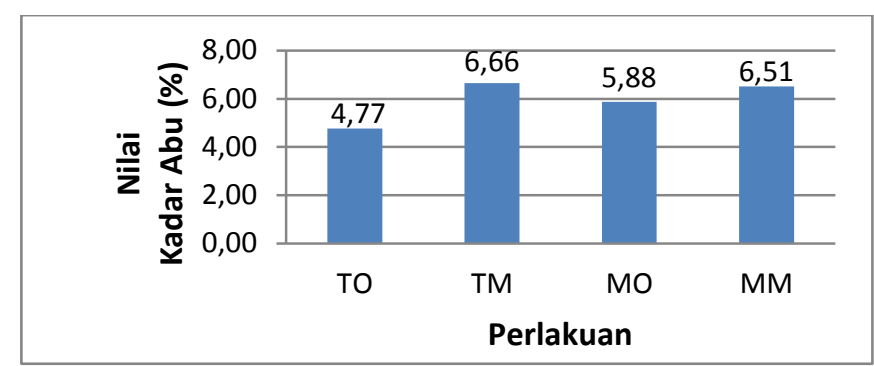

Gambar 6. Grafik rata-rata nilai kadar abu teh herbal daun pala tua dan muda dengan dua jenis pengeringan.

Berdasarkan Gambar 6, terlihat bahwa kadar abu pada teh herbal daun pala tua dan muda dengan dua jenis pengeringan yaitu oven dan matahari berkisar antara 4,77\%-6,66\%. Nilai kadar abu yang terendah yaitu $4,77 \%$ pada perlakuan TO, dan yang tertinggi yaitu $6,66 \%$ pada perlakuan TM. Hasil penelitian diatas menunjukkan bahwa dari semua perlakuan diketahui bahwa jenis pengeringan dan umur daun sangat berpengaruh pada nilai kadar abu yang dihasilkan. Semakin tua umur daun maka semakin rendah nilai kadar abu yang dihasilkan dan semakin lama proses pengeringan maka semakin tinggi kadar abu pada bahan yang dihasilkan. Menurut Darmajana (2007), bahwa dengan bertambahnya suhu dan lama pengeringan maka kadar abu cenderung meningkat. Kadar abu teh herbal daun pala ini memiliki nilai yang lebih rendah dibanding dengan nilai kadar abu pada ketetapan SNI yaitu maksimal 8\%. Kandungan abu dari suatu bahan menunjukkan kadar mineral dalam bahan tersebut (Muchtadi ,1989).

Hasil analisis sidik ragam menunjukkan bahwa perlakuan umur daun dan jenis pengeringan berbeda nyata dan ada interaksi antara kedua faktor tersebut. Abu merupakan komponen mineral yang tidak mengguap pada proses pembakaran atau pemijaran senyawa-senyawa organik. Hasil Beda Nyata Terkecil (BNT) nilai kadar abu pada interaksi anatar umur daun dan jenis pengeringan dapat disimpulkan bahwa teh herbal daun pala berbeda antara TO, TM, MO dan MM. Hal ini menunjukkan bahwa semakin lama proses pengeringan dan semakin tua umur daun maka semakin rendah kadar abu pada bahan yang dihasilkan.

Tabel 8. Kadar Abu Akibat Pengaruh Umur Daun dan Jenis Pengeringan Pada Uji BNT $t_{(0,05)}$ $=0,061$

\begin{tabular}{ccc}
\hline Perlakuan & Rata-rata & Notasi \\
\hline TO & 4,77 & $\mathrm{a}$ \\
TM & 6,66 & $\mathrm{c}$ \\
MO & 5,88 & $\mathrm{~b}$ \\
MM & 6,51 & $\mathrm{c}$ \\
\hline
\end{tabular}

Keterangan : subscript yang diikuti huruf yang sama dinyatakan tidak berbeda nyata pada uji BNT $t_{(0,05)}$

\section{Kadar Serat Kasar}

Serat mempunyai peran yang penting bagi kesehatan tubuh, Almatsier (2009) menyatakan bahwa serat sangat penting alam proses pencernaan makanan dalam tubuh. Kekurangan serat 
Lestari, M., dkk. Teh herbal daun pala, daun pala, umur daun pala, jenis pengeringan, sifat kimia, sifat organoleptik

dapat menyebabkan konstipasi, hemoroid, diabetes melitus, penyakit jantung koroner dan batu ginjal.

Analisa rata-rata nilai kadar serat kasar teh herbal daun pala tua dan muda dengan dua jenis pengeringan dapat dilihat pada Gambar 7.

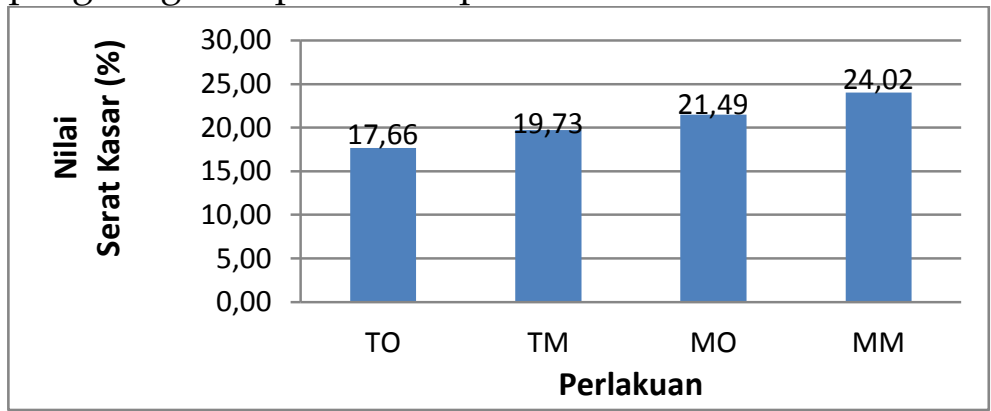

Gambar 7. Grafik rata-rata nilai kadar serat kasar teh herbal daun pala tua dan muda dengan dua jenis pengeringan

Berdasarkan Gambar 7, terlihat bahwa kadar serat kasar pada teh herbal daun pala tua dan muda dengan dua jenis pengeringan yaitu oven dan matahari berkisar antara 17,66\%-24,02\%. Nilai serat kasar yang terendah yaitu $17,66 \%$ pada perlakuan TO dan yang tertinggi yaitu 24,02\% pada perlakuan MO. Kadar serat kasar herbal daun pala ini memiliki nilai yang lebih tinggi dibanding dengan nilai kadar serat kasar pada ketetapan SNI yaitu maksimal 16\%. Hasil penelitian diatas menunjukkan bahwa dari semua perlakuan diketahui bahwa semakin muda umur daun pala maka semakin tinggi kadar serat kasarnya. Sementara daun teh mengandung selulosa sebesar $7 \mathrm{~g} / 100 \mathrm{~g}$ bk (Robertson, 1992).

Hasil analisis sidik ragam menunjukkan bahwa perlakuan umur daun dan jenis pengeringan berbeda nyata. Hal ini menunjukkan bahwa ada interaksi antara umur daun pala dan jenis pengeringan yang mempengaruhi nilai serat kasar yang dihasilkan. Serat kasar menurut Muchtadi (1989) residu dari makanan yang tidak dapat dihidrolisis dengan bahan kimia.

Hasil BNT (beda nyata terkecil) nilai rata-rata kadar air teh daun pala akibat pengaruh umur daun dan jenis pengeringan berbeda nyata. Nilai tertinggi kadar air pada pengaruh umur diperoleh pada perlakuan daun tua $(\mathrm{T})$ yang berbeda nyata dengan perlakuan daun muda $(\mathrm{M})$ sedangkan jenis pengeringan diperoleh pada perlakuan oven $(\mathrm{O})$ yang berbeda nyata dengan perlakuan matahari (M). Hal ini menunjukkan bahwa semakin muda umur daun dan semakin lama proses pengeringan maka akan semakin tinggi nilai serat kasar yang dihasilkan. Hal ini diduga berkurangnya air dalam bahan membuat nilai serat kasar yang dihasilkan pada bahan akan semakin meningkat sehingga nilai yang didapat cenderung naik. 
Tabel 9. Kadar Serat Kasar Akibat Pengaruh Umur Daun dan Jenis Pengeringan Pada Uji BNT $t_{(0,05)}=1,595$

\begin{tabular}{ccc}
\hline Perlakuan & Rata-rata & Notasi \\
\hline Umur & & \\
\hline Tua & 17,66 & a \\
Muda & 21,49 & b \\
\hline Pengeringan & & \\
\hline Oven & 19,73 & a \\
Matahari & 24,02 & b
\end{tabular}

Keterangan: subscript yang diikuti huruf yang sama dinyatakan tidak berbeda nyata pada uji BNT $t_{(0,05)}$

\section{Analisis Sifat Organoleptik}

Pada analisa sifat organoleptik, parameter pengamatan adalah meliputi rasa, aroma dan warna.

\section{A. Rasa}

Rasa dari teh dapat dinilai dengan menggunakan indera pengecap. Umumnya bahan pangan tidak hanya terdiri dari salah satu rasa tetapi merupakan gabungan berbagai macam rasa secara terpadu sehingga menimbulkan rasa yang utuh. Kecuali itu rasa suatu bahan pangan merupakan hasil kerjasama indera- indera yang lain. Dalam mengindera rasa larutan sampel, panelis diharuskan untuk merasakan dengan menggunakan indera pencecap, yaitu lidah. Untuk dapat merasakan secara optimal, larutan dapat diratakan pada seluruh permukaan lidah. Pada permukaan lidah terdapat sel-sel papilla yang didalamnya terdapat kuncupkuncup (bud) yang jika terangsang akan meneruskan rangsangan tersebut ke otak sehingga timbul kesan rasa (Bambang et.al. 1988).

Hasil pengujian tingkat kesukaan rasa teh herbal daun pala tua dan muda dengan dua jenis pengeringan disajikan pada Gambar 8.

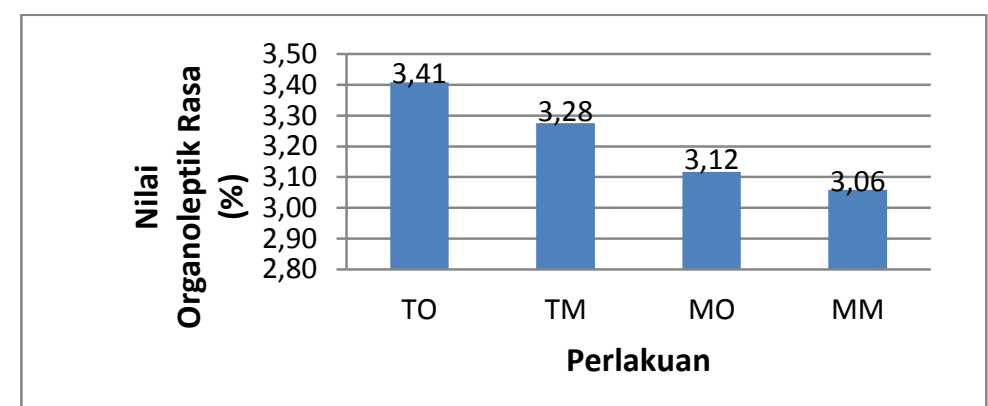

Gambar 8. Grafik rata-rata rasa teh herbal daun pala tua dan muda dengan dua jenis pengeringan

Berdasarkan Gambar 8, menunjukkan bahwa hasil keseluruhan analisis rata-rata penilaian panelis terhadap rasa teh herbal daun pala tua dan muda dengan dua jenis pengeringan 
Lestari, M., dkk. Teh herbal daun pala, daun pala, umur daun pala, jenis pengeringan, sifat kimia, sifat organoleptik

berkisar antara 3,06-3,41 (netral). Dilihat dari total seluruh perlakuan, nilai rata-rata rasa teh herbal daun pala tua dan muda dengan dua jenis pengeringan dengan nilai yang terendah yaitu 3,06 (netral) terdapat pada perlakuan MM dan yang tertinggi yaitu 3,41 (netral) terdapat pada perlakuan TO. Hal ini menunjukkan bahwa panelis cenderung memberikan penilaian netral pada semua perlakuan.

Hasil analisis sidik ragam menunjukkan bahwa ada interaksi pada umur daun dan jenis pengeringan berbeda nyata. Hal ini menunjukan umur daun dan jenis pengeringan berpengaruh terhadap parameter rasa yang dihasilkan. Hal ini diduga disebabkan oleh perlakuan umur daun yang berbeda dan juga perlakuan pengeringan yang digunakkan, sehingga rasa yang didapat berbeda, rata-rata panelis juga beranggapan bahwa semua sampel yang diuji memiliki aroma yang berbeda.

Hasil BNT Nilai rata-rata organoleptik parameter rasa teh herbal daun pala akibat pengaruh umur daun dan jenis pengeringan berbeda nyata. Nilai tertinggi parameter rasa pada pengaruh umur diperoleh pada perlakuan daun muda $(\mathrm{M})$ yang berbeda nyata dengan perlakuan daun tua $(\mathrm{T})$ sedangkan jenis pengeringan diperoleh pada perlakuan matahari (M) yang berbeda nyata dengan perlakuan oven $(\mathrm{O})$. Hal ini menunjukkan bahwa umur daun dan jenis pengeringan berpengaruh terhadap parameter tingkat kesukaan rasa pada teh herbal daun pala.

Tabel 10. Parameter Rasa Akibat Pengaruh Umur Daun dan Jenis Pengeringan Pada Uji BNT $t_{(0,05)}=0,052$

\begin{tabular}{ccc}
\hline Perlakuan & Rata-rata & Notasi \\
\hline Umur & & \\
\hline Tua & 3,28 & ab \\
Muda & 3,12 & $\mathrm{a}$ \\
\hline Pengeringan & & \\
\hline Oven & 3,41 & ab \\
Matahari & 3,06 & $\mathrm{a}$
\end{tabular}

Keterangan : subscript yang diikuti huruf yang sama dinyataka tidak berbeda nyata pada uji BNT $t_{(0,05)}$

\section{B. Aroma}

Salah satu faktor yang menentukan mutu suatu bahan makanan dapat diterima oleh konsumen adalah aroma. Aroma merupakan indikator yang terpenting dalam industri pangan karena dengan cepat dapat memberikan hasil penilaian diterima atau tidaknya produk tersebut. Menurut Winarno (1990), aroma makanan menentukan kelezatan makanan tersebut.

Hasil pengujian tingkat kesukaan aroma teh herbal daun pala tua dan muda dengan dua jenis pengeringan disajikan pada Gambar 9. 


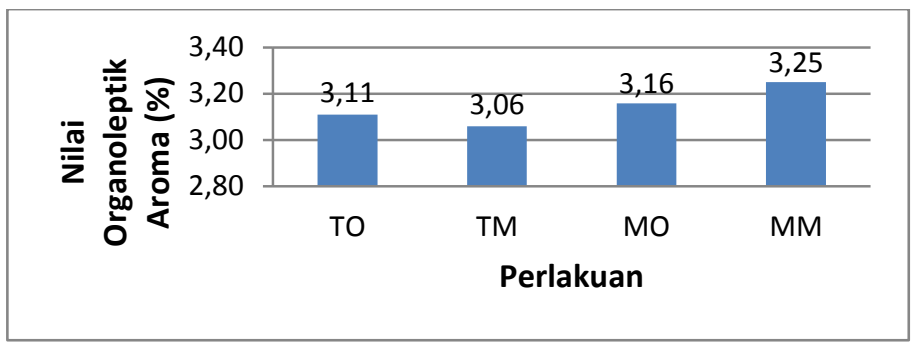

Gambar 9. Grafik rata-rata aroma teh herbal daun pala tua dan muda dengan dua jenis pengeringan.

Berdasarkan Gambar 9, menunjukkan bahwa hasil keseluruhan analisis rata-rata penilaian panelis terhadap aroma teh herbal daun pala tua dan muda dengan dua jenis pengeringan berkisar antara 3,08-3,48 (netral). Nilai rata-rata aroma teh herbal daun pala tua dan muda dengan dua jenis pengeringan yang terendah yaitu 3,08 (netral) terdapat pada perlakuan MM, dan yang tertinggi yaitu 3,48 (netral) terdapat pada perlakuan TM. Dari data diatas terlihat jelas bahwa jenis pengeringan matahari yang memiliki nilai aroma yang tertinggi. Dari hasil nilai rata-rata diatas menunjukkan bahwa panelis cenderung beranggapan semua sampel netral.

Hasil analisis sidik ragam menunjukkan bahwa aroma teh herbal daun pala tua dan muda dengan dua jenis pengeringan tidak berbeda nyata. Hal ini karena panelis cenderung beranggapan semua warna teh yang dihasilkan sama meskipun memiliki perlakuan yang berbeda.

\section{Warna}

Warna pada makanan dan minuman merupakan hal utama yang dapat menarik perhatian konsumen. Warna dapat dilihat melalui indra penglihatan yaitu mata. Menurut Astawan (2002), warna juga penting dalam makanan baik yang diproses maupun tidak diproses dan warna juga memberi petunjuk mengenai perubahan kimia dalam makanan.

Hasil pengujian tingkat kesukaan warna teh herbal daun pala tua dan muda dengan dua jenis pengeringan disajikan pada Gambar 10.

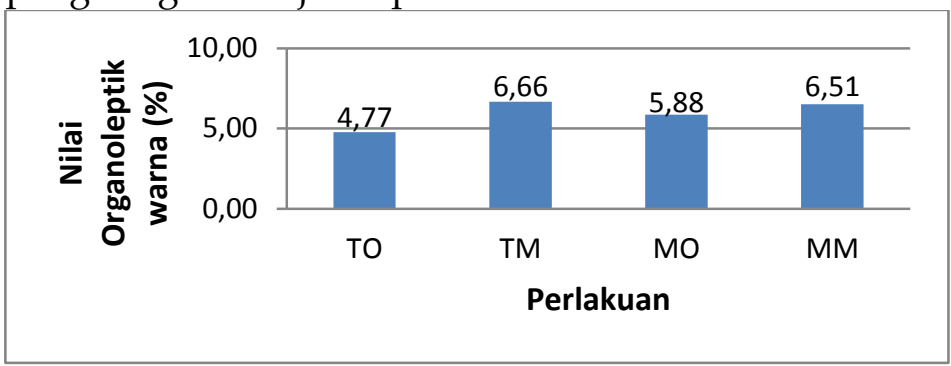

Gambar 10. Grafik rata-rata warna teh herbal daun pala tua dan muda dengan dua jenis pengeringan.

Berdasarkan Gambar 10, menunjukkan bahwa rata-rata penilaian penelis terhadap warna teh herbal daun pala tua dan muda dengan dua jenis pengeringan berkisar antara 3,06-3,25 (netral). Warna teh herbal daun pala tua dan muda dengan dua jenis pengeringan memilki nilai terendah yaitu 3,06 (netral) pada perlakuan TM dan yang tertinggi yaitu 3,25 (netral) 
Lestari, M., dkk. Teh herbal daun pala, daun pala, umur daun pala, jenis pengeringan, sifat kimia, sifat organoleptik

pada perlakuan MM. Dari data tersebut terlihat bahwa pengeringan oven memiliki nilai warna yang lebih tinggi dibandingkan perlakuan pengeringan menggunakan matahari, dikarenakan warna dari perlakuan TM cenderung berwarna hijau kecoklatan hampir mirip dengan teh pada umumnya sehingga panelis lebih menyukai warna dari perlakuan tersebut. Dilihat dari grafik nilai rata-rata warna diatas menunjukan bahwa panelis tidak menyukai warna dari teh yang dihasilkan karena ada pada skala 1 dan 2, yaitu tidak suka dan sangat tidak suka.

Hasil analisis sidik ragam menunjukkan bahwa warna teh herbal daun pala tua dan muda dengan dua jenis pengeringan tidak berbeda nyata. Hal ini karena panelis cenderung beranggapan semua warna teh yang dihasilkan sama meskipun memiliki perlakuan yang berbeda.

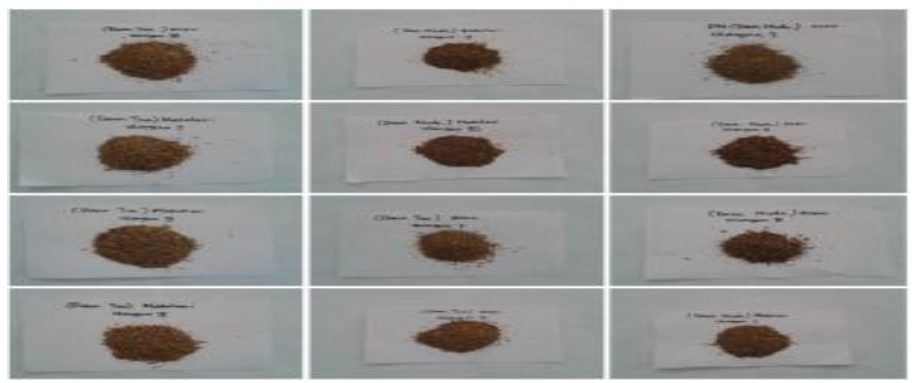

Gambar 11. Sampel teh

\section{KESIMPULAN}

Berdasarkan sifat kimia dan sifat organoleptik yang dilakukan, maka dapat ditarik kesimpulan sebagai berikut :

1. Teh herbal daun pala perlakuan terbaik yaitu daun pala muda dengan pengeringan matahari (MM).

2. Teh herbal daun pala tua dan muda dengan dua jenis pengeringan berpengaruh terhadap sifat kimia pada parameter aktivitas antioksidan, kadar air, kadar abu, serat kasar, rasa dan warna.

3. Teh herbal daun pala ini aman dikonsumsi karena tidak menggunakan bahan pengawet maupun bahan tambahan berbahaya.

\section{SARAN}

Saran yang dapat diberikan adalah sebagai berikut :

1. Perlu adanya penelitian lebih lanjut mengenai pembuatan teh dengan jenis pengeringan yang lain contohnya kabinet drying.

2. Perlu dilakukan penelitian tentang umur simpan teh herbal daun pala.

\section{DAFTAR PUSTAKA}

Almatsier, Sunita. 2009. Prinsip Dasar Ilmu Gizi. Gramedia Cetakan IX, Jakarta. 
Astawan, Made. 2004. Tetap Sehat dengan Produk Makanan Olahan. Solo: PT. Tiga Serangkai.

Bambang, Kartika, dkk., 1988. Pedoman Uji Inderawi Bahan Pangan. PAU Pangan dan Gizi UGM, Yogyakarta.

[BPS Malut] Badan Pusat Statistik Provinsi Maluku Utara. 2014. Produksi Pala di Maluku Utara. BPS Maluku Utara, Ternate.

Darmajana, A. D. 2007. Pengaruh Konsentrasi Natrium Bisulfit Terhadap Mutu Tepung Inti Buah Nemu. Seminar Nasional Teknik Kimia, Yogyakarta.

Fajriah, S., Darmawan, A., Sundowo., A., \& Artanti, N. 2002. Isolasi senyawa antioksidan dari ekstrak etil asetat daun benalu (dendrophthoe pentandra L. mia) yang tumbuh pada inang lobi-lobi. Jurnal kimia Indonesia. 2(1): 17-20. Yogyakarta.

Hartati, Sri. 2009. Pusat Penelitian Bioteknologi LIPI. Bandung.

Muchtadi ,D. 1989. Petunjuk Laboratorium : Evaluasi Nilai Gizi Pangan. Depdikbud-Dirjen dikti, PAU Pangan dan Gizi. IPB : Bogor.

Murtiningrum. 2005. Ekstraksi Minyak Dengan Metode Wet Rendering Dari Buah Pandan (Pandanus conoideus) dan Pemurnian Dengan Filtrasi Membran. Jurnal Teknologi Indonesia. 15(1):28-33.

Rastuti, K. N. 2013. Aktivitan Antibakteri Minyak Atsiri Daun Pala Dari Banyumas Terhadap Staphylococcus aureus Dan Escherichia coli Serta Identifikasi Senyawa Penyusunannya. Jurnal Ilmiah Kimia Molekul 8(2): 1-7.

Robertson,L.G.,(1992)"Food Packaging Principles and Practice" Marcell Dekker.Inc.New York.

Roni, M. A. 2008. Formulasi minuman herbal instan antioksidan dari campuran teh hijau (Camellia sinensis), Pegagan (Centella asiatica), dan daun jeruk purut (Cytus hystrix). Skripsi S1.Institut Pertanian Bogor. (tidak dipublikasikan).

Sari, M. A. 2013. Aktivitas Antioksidan Teh Daun Alvokad (Persea Americana Mill) Dengan Variasi Teknik dan Lama Pengeringan. Skripsi. Universitas Muhammadiyah, Surakarta.

Syarief, R. dan H. Halid. 1993. Teknologi Penyimpanan Pangan. Arcan, Jakarta.

Winarno, F.G., 1993. Kimia Pangan dan Gizi.. Gramedia Pustaka Utama, Jakarta. 